Years Immediately After the Second World War: a British Perspective' (D. Ph. Thesis, Oxford University, 1988) and John Knape, 'H.M.G. and Responses to Economic Nationalism: British Public Utility Companies in Latin America, 1930-1956' (Univ. of Liverpool, Institute of Latin American Studies, undated).

16 See F.O. 371 A1461/1954 (file); Foreign Office minute by K.R.C. Pridham, London, 8 Jan. 1954, F.O. $371 \mathrm{A1} 461 / 2$ and The Times, 13 July 1955, 13.

17 For the company's decision to seek an understanding with Pern see 'Memorandum from the Anglo Argentine Transways Co. Ltd.', confidential, London, 29 Mar. 1954, F.O. 371 A1461/14.

18 For the interview see N.T. Kennedy note on the meeting of the local representatives with Finance Minister Gómez Morales on 9 Mar. 1954, F.O. 371 Al461/3.

19 Crick to Turner, Buenos Aires, 10 Nov. 1955 and Bank of England minutes, London, 28 April and 31 May 1956, BEA: Argentina OV101/32 and OV102/36; The Times, 1 Sept. 1956, 12 and La Prensa, 1 Sept. 1956, 1. For the Anglo's situation see Foreign Office minute by F.S. Vincent, London, 18 Jan. 1956, F.O. 371 A1461/4; Foreign Office to British embassy in Buenos Aires, coded telegram, London, 27 Jan. 1956, F.O. 371 A1461/ 5; Foreign Office minute, London, 25 June 1956, F.O. 371 A1471/7 and F.O. 371 A1461/ 34 (1957).

20 For the internal discrepancies within the Argentine government see minute of a conversation between Dr. Raúl Prebisch and Mr. Greville John Macgillivray, from the Bank of England, on 14 Mar. 1956, F.O. 371 Al121/59; and report on a visit to Argentina by Mr. G.J. Macgillivray, London, 6 Dec. 1956, BEA: OV102/41.

21 Correspondence between President Frondizi and ambassador Hartung in London in Centro de Estudios Nacionales, Buenos Aires, Archivo Arturo Frondizi, Gran Bretaña, ' $R$ ' (hereafter cited as CEN: Frondizi Archive and folder name or number); Ministerio de Relaciones Exteriores y Culto, Misión Alsogaray a Europa, 1961, secreto, CEN: Frondizi Archive; 'Presidencia de la Nación, Recomendaciones Para la Misión a Europa y Estados Unidos', estrictamente confidencial, Buenos Aires, 9 Nov. 1961, CEN: Frondizi Archive, Carpeta Asuntos Económicos, 4 (8) and 'Informe de la Misión Económica a Europa Encomendada al Dr. Roberto T. Alemann Mediante el Decreto 10.476/61', Buenos Aires, 26 Dec. 1961, CEN: Frondizi Archive, Carpeta Confederación General Económica-Economia-Alemann (Folio I). For samples of the company's demands see Rennie to Hankey, mia-Ale 26 Sept. 1958, F.O. 371 A1462/13 and Docker to the Chancellor of the Exchequer, London, 18 Dec. 1959, BEA: Argentina, OV102/204.

chequer, London, 18 Dec. 1959, BEA: Argentina, OV102/204.

. London, 5 May 1961, F.O. $371 \mathrm{~A} 1464 / 10$.

23 See a minute by Leslie Crick, London, 9 Aug. 1962 and ambassador Middleton to the Foreign Secretary, confidential, Buenos Aires, 10 Aug. 1962, BEA: Argentina OV102/84.

24 See Edmonds to Thompson, confidential, London, 15 Sept. 1961, F.O. 371 A1464/19; Treasury minute by K.S. Weston, London, 4 Jan. 1961, BEA: Argentina OV102/74.

25 For the verdict and the settlement see The Times, 8 Oct. 1965, 12; La Nacion, 7 Oct. 1965 7 and 29 Dec. 1966, 1; Annales de legrslación argentina XXVI-C (1966) 1, 649-650 and The Stock Exchange Official Year-Book (London) I (1968) 1, 494.

26 These were a British concern, the Primitiva Gas Co. of Buenos Aires, a U.S. electricity company, the American and Foreign Power, and a French company that operated a major port, the Sociedad Anónima del Puerto de Rosario

27 For a sample of this resentment against the Anglo see 'Las Sanguijelas de Ultra mar', El Lider (Buenos Aires), 31 Oct. 1946, 12.

\section{The Issue of Forced Labour in the Onjembo: German South West Africa 1904-1908}

\author{
JAN-BART GEWALD* \\ (Leiden University)
}

Visitors to the sea-side resort of Swakopmund on the Namibian coast will have often stood on the northern banks of the Swakop river and marvelled at the sea of sand dunes that commences on the opposite side of the river. Very few of them will ever have realised that they were standing upon, and wandering amongst, the mass graves of Herero and Nama prisoners of war, who between 1904 and 1908 were employed as forced labourers. As I write the mass-graves of Swakopmund are used by recreationers as a testing ground for their four-wheel-drive off-road vehicles, perhaps in the future the true nature of these graves will come to be realised and appreciated.

In January 1904 the Onjembo, the Herero-German war, broke out. During the course of seven mon ths the Herero were driven back from their ancestral homes and lands, and forced to retreat into the north-eastern reaches of the then German colony of South West Africa, the present-day Republic of Namibia. In August 1904 the last major battle of the Onjembo was fought at the wells of Hamakari at the foot of the Waterberg in north-eastern Namibia.

Following their defeat at Hamakari, the surviving Herero were driven north-eastward into the Omaheke region of the Kalahari desert basin. ${ }^{1}$ The water holes and wells located along the south-western fringes of the Omaheke were occupied by German troops and patrols were sent deep into the Omaheke in pursuit of the fleeing Herero. ${ }^{2}$ This pursuit was only called off by the German Government, once it had become known that a Vernichtungsbefehl [extermination order] had been issued by General Von Trotha, the commander in chief of German troops in Namibia at the time. Captured prisoners were forced to watch the summary execution of their fellow prisoners, whereafter they were issued with printed texts of the Vermichtungsbefehl, in the Herero language, and sent off after their fleeing colleagues. ${ }^{3}$ Part of the General's text read as follows:

I am the great General of the Germans. I am sending a word to you Hereros, you who are Hereros are no longer under the Germans. You have stolen, killed and owe white people. You have cut 
ears and noses, but now out of cowardice say you will not fight. am saying to you Herero, you who are great, anyone who catches and brings a chief will be paid 50 pounds, especially chief Samuel Maharero shall fetch 250 pounds. ${ }^{4}$ You Hereros must now leave this land as it belongs to the Germans. If you do not do this I shall remove you with the big gun. A person in German land shall be killed by the gun. I shall not catch women and the sick but I will chase them after their chiefs or I will kill them with the gun. These are my words to the Herero nation.

The Great General of the Kaiser

Trotha. ${ }^{5}$

The order unleashed a storm of protest in the German Reichstag and shortly thereafter Von Trotha was forced to rescind his declaration. Instead he now recommended that captured Herero be placed in chains and distributed as labour throughout the colony. ${ }^{6}$ The following is part of the text which was subsequently issued in an attempt at enticing the Herero to surrender:

To the Herero people hear my words, the German Kaiser my great lord, wrote a letter to the great General von Trotha and said, 'Make peace with the Herero and grant them their lives, do not kill them any more."

Prior to the battle of Hamakari German commanders had already received requests from settlers for the allocation, for labour purposes, of a number of the prisoners of war which they were expected to make. These requests were not surprising. With the expulsion of the Herero frum most of the central Namibian settler farms, the perceived Herero threat had diminished and at the same time, a dire labour shortage had developed in the civilian sector of the colony's settler economy. As the war approached its climax the settler economy, which serviced the German military presence, started picking up again and the demand for labour increased. Given that from the very beginning of hostilities the German army had employed prisoners of war as forced labour and that it was anticipated that the German army would make a large number of prisoners of war, it is not surprising that settlers applied to its commanders for labour. A fine example of one such request is the following:

According to reports, large numbers of Herero have already been captured in the battles at the Waterberg. Bearing in mind that the containment and maintenance of large numbers of prisoners in Damaraland [Central Namibia] is likely to be bound up with major difficulties, the Gibeoner Schiff- und Handelsgesellschaft has submitted an application that of these prisoners they be immediately granted ca. 50-100 men as mine workers. [...] It is perhaps advisable that the Herero be chained together in groups of about ten men before transported south. ${ }^{8}$

As the Herero-German war wound down in northern and central Namibia and the Nama-German war developed in the southern reaches of the country, the military and settler demands for labour, and the concomitant shortage of labour, developed continually. However, as a direct result of the German military successes, most of the Herero who had survived the armed battles of the war were confined to the dry regions of the Omaheke, and could thus not be approached for labour purposes. With this in mind the German Reichskanzler recommended that missionaries be asked to encourage the Herero to surrender and that those Herero who surrendered were 'to be placed in concentration camps [Konzentrationslagern] in various parts of the country where, under guard, they could then be used for labour' 9

With the effective containment of the Herero survivors, within the desert regions of the Omaheke, missionaries of the Rhenish Missionary society and their assistants were sent into the Omaheke to lure the survivors out and into the newly established camps. In anticipation of the new prisoners a number of holding camps were set up in Omburo, Otjosazu, Otjihaenena and later Otjozongombe. ${ }^{10}$ Given the circumstances, the missionaries were extremely successful in enticing large numbers of Hereros, starved, pursued and hunted like animals, out of the desert. The captives were placed in camps, from whence they were then redistributed to smaller camps all around the country. The Herero interned in these camps were to be used as forced labour.

Though civilians had demanded, from the very beginning of the war, that they be permitted access to the captured Herero for labour purposes, it was not until 1905 that, following lengthy discussions, it was decided that civilians and civilian businesses would also be permitted to employ captured Herero for labour purposes. ${ }^{11}$ Henceforth civilians could apply to the military for labour. Once the military needs had been fulfilled, captured labour was to be made available to civilians: 'The district authorities will determine the number of prisoners required for labour purposes and will inform the military authorities [Etappenkommando] accordingly. Bearing in mind the number of prisoners available, the military authorities will allocate, to the district authorities, prisoners, who will then be allocated to the individual applicants according to their importance and need. [. . .] As prisoners they are not to be paid for their labour [ . . ] ${ }^{12}$ Henceforth civilians could collect their daily allotments from the various camps, whilst large civilian companies, such as the Woermann shipping company, maintained their own camps. $^{13}$

The prisoners were used by both military and civilian enterprises for a wide range of activities. Civilian authorities regularly petitioned the military 
authorities for additional labour. The following partial transcript of a telegram sent on behalf of the Swakopmund chamber of commerce is a fine example of this petitioning:

The civil economic community, excepting the Woermann line [shipping company], require 300 Natives fit for labour for the maintenance and continuance of their companies, [...] therefore we request your excellency that a big transport of native prisoners of war be handed over to the district administration for distribution

by the civilian administration. ${ }^{14}$

Prisoners were used as labour by the various civilian companies, ranging from laundries to transport contractors, breweries and shipping companies. ${ }^{15}$ The various military units used their prisoners, often children, primarily for the maintenance and care of their stock, the construction of cattle kraals, the pumping of water, and the cutting of grass for fodder and herding. ${ }^{16}$ The German colonial civil administration employed Herero and later Nama prisoners of war primarily on the building of railway lines between Usakos and Otavi and later between Lüderitz and Keetmanshoop. ${ }^{17}$ The civil administration also employed prisoners on building projects, one of which led to the construction of what is today the building that houses the parliament of independent Namibia. ${ }^{18}$

Apart from the texts provided by both the civilian and military authorities we also have extremely detailed reports written by the missionaries, who were actively involved in the herding of Herero into the camps and who were permitted to work in these camps. The missionary chronicles for Swakopmund provide us with a clear image of conditions in these camps:

When missionary Vedder arrived in Swakopmund in 1905 there were very few Herero present. ${ }^{19}$ Shortly thereafter vast transports of prisoners of war arrived. They were placed behind double rows of barbed wire fencing, which surrounded all the buildings of the harbour department quarters [Hafenamtswerft], and housed in pathetic [jammerlichen] structures constructed out of simple sacking and planks, in such a manner that in one structure 30-50 people were forced to stay without distinction as to age and sex. From early morning until late at night, on weekdays as well as on Sundays and holidays, they had to work under the clubs of raw overseers [Knutteln roher Aufseher], until they broke down [zusammenbrachen]. Added to this the food was extremely scarce: rice without any necessary additions was not enough to support their bodies, already weakened by life in the field [as refugees] and used to the hot sun of the interior, from the cold and restless exertion of all their powers in the prison conditions of Swakopmund. Like cattle hundreds were driven to death and like cattle they were buried. This opinion may appear hard or exaggerated, lots changed and became milder during the course of the imprisonment $[\ldots]$ but the chronicles are not permitted to suppress that such a remorseless rawness [rücksichtslose Roheit], randy sensuality [geile Sinnlichkeit], brutish overlordship [brutales Herrentum] was to be found amongst the troops and civilians here that a full description is hardly possible. ${ }^{20}$

The conditions in Swakopmund were bad. The presence of Vedder partly ensured that the military authorities were forced to institute an investigation into the state of affairs. The investigation concluded that in the interests of labour the prisoners 'be provisioned and strengthened in the interior before being sent here'. ${ }^{21}$ In Lüderitz conditions were if anything worse than in Swakopmund. Initially missionaries were not present in Lüderitz. It was only later that, acting on reports of Herero evangelists who had been sent there, they voiced their deep concern to the authorities. ${ }^{22}$

One of the aspects of the forced labour system was that the district authorities were ordered to submit monthly reports to the central government as to 'how many prisoners, categorised as men, women and children, found within the district authorities area, had been allocated to civilians or to the government itself ${ }^{23}$ Because these lists were to provide the German authorities with an indication as to the labour available, they also included the categorisation fit or unfit [Arbeitsfähig, Unfähig] for labour purposes. ${ }^{24}$ In the case of Swakopmund the district authorities' list was accompanied by a death register [Totenregister], which listed the cause of death as either exhaustion, heart failure, bronchitis or scurvy. Furthermore the list contained roneoed death certificates which already listed the cause of death as 'death by exhaustion following privation'. These only needed to be filled in for a tally to be kept of the daily dead. ${ }^{25}$

However it was not all a one way affair. Herero prisoners of war not only died, they also resisted and fled. The files of the magistrate court in Lüderitz make ample mention of Herero prisoners of war, men as well as women, who had been put to work on the construction of a railway line from Lüderitz to Aus, and who actively resisted, often for nought, the mistreatment to which they were subjected..$^{26}$ As the war continued large numbers of refugees fled to the comparative safety of the British territory of Walvisbay. According to German intelligence reports, the postman, operating between Swakopmund and Walvisbay, acted as a go-between for labour recruiters, stationed in Walvisbay and working on behalf of the South African mines, and the prisoners in Swakopmund. ${ }^{27}$ Between 1905 and April 1908, when the camps were finally abolished, hundreds of prisoners fled Swakopmund. So much so that the Woermann shipping company, a major recipient of the forced labour, was often short of harbour labour. As a missionary, who was working in Swakop at the time, noted:

Timotheus Hipangua, fled with wife and child and many others in the night of 4 Nov 1906 to Walvisbay. Many had preceded him and 
many would follow him, to swop their toiling existence here for

an existence of tedium in the mines of South Africa. ${ }^{28}$

Finally, in 1908 the camps were abolished..$^{29}$ Instead, the former prisoners of war were subjected to stringent labour and pass laws. Henceforth all Herero over the age of seven were expected to carry metal disks around their necks. These bore a number that corresponded with a number in a register that kept track of allocated 'free' labour. ${ }^{30}$ Some registers, which had been used to keep control of the allocations of forced labour, were retained and used to list the allocation of labour according to the new pass and labour laws. ${ }^{31}$

This article contradicts the claims of those who write about the German Herero war and state that: "There is absolutely no evidence [...] that the Herero perished or were used on a large scale as "slave labourers".'32 One short look at any of the German colonial government files entitled Kriegsgefangene [prisoners of war], stored in the Namibian national archives in Windhoek, will disprove these claims.

Notes

* This paper was prepared for the 'Forced Labour in Comparative Context' session of the International Economic History Congress, Milan, September, 1994. With sincere thanks to the staffs of the archives of the Evangelical Lutheran Church in Namibia, Namibian Natıonal Archives Windhoek, Bundes-Archiv Potsdam, Botswana National Archives in Gaborone and the Cape Archives Depot in Cape Town, and to the Office of the President of the Republic of Botswana for permission to conduct research in Botswana. For financial assistance thanks to the Netherlands Organization for Scienufic Research (NWO) and the Netherlands foundation for tropical research (WOTRO)

1 Omaheke is translated from Otjiherero as dry coarse sands, and is generally used to refer to a specific region of Namibia

2 For a detaled blow by blow account of the war see Gerhardus Pool, Dre Herero-opstand 1904-1907 (Cape Town 1979)

3 Conrad Rust, Kneg und Freden im Hererolande Aufzerchnungen aus allem Knegsjahre 1904 (Berlın 1905) 386.

4 The use of pounds as legal currency for monetary transacuons in German South West Africa was widespread Unlıke German East Africa no local currency was minted, though the German authontues did prohibit the use of foreign copper coins after 1893 It was only following 1 February 1905, that German Marks became the sole legal currency in Germany's protectorates and thus also in GSWA Heinrich Schnee, Deutsches Kolonial Lexzkon (Leıpzig 1920) With thanks to D Hennchsen for finding this reference
5 Luteral translation of Otylherero language document found in Botswana National Archives (BNA) R.C. 11/1, with thanks to Kovhende Kaotozu for the translation A German copy of the text is to be found in Nambian National Archives (NNAW), ZBU D 1.a Band 34, Blatt 165 . With thanks to $\mathrm{Mr} \mathrm{W}$ Hillebrecht for finding the text.

6 NNAW, ZBU 454, Telegram Von Trotha in Windhuk, 5/1/5 to Reichskanzler. A short whle later Von Trotha was forced to rescind this order as well and henceforth only while later Von Trotha was fored to rescind this order as well and henceforth only 'troublemakers' were to be chaned. NNAW, A. 508, Telegrams 1905, Donor Dr. Sinke, 1988; 7f, Telegram from Von Trotha in Windhuk 16/1/05
POWs (photocopies of onginals in the Potsdam archives RKA 2089).

7 NNAW, STR Kazserliche Schutztruppe fur DSWA, STR I Gefangene wāhrend des Aufstandes, Subfile 1 a5.

8. NNAW, ZBU 454, Kaiserlıches Bezırksamt Gibeon, 18/8/04 an das Kaıserliche Gouvernement. Author's translation.

9 NNAW, ZBU 454 D IV 1.3. Band 1, Telegramm des Reichskanzlers an das Gouvernement elngegangen am 14 Januar 1905

10 Evangelical Lutheran Church in Namibia (ELCIN), V Chroniken Omaruru 1905 \& II 9.1,7 Privatbrief von Missionar J Bohm aus der Aufstandszeıt $1904 \mathrm{ff}$ aus Walfischbay

11 NNAW, BWI 406, Akten E.V.8 Knegsgefangene Eingeborene generalıa begonnen 1/4/ 05-31/3/09. Rundverfügung Windhuk, 6 April 1905, der Kasserlıche Gouverneur in Vertretung Fecklenburg Abkommen des Gouvernements mit der Militar-behörde betreffs Überweisung von Knegsgefangenen

12 NNAW, ZBU 454, D IV 1.3 Band 1, Bericht, Etappenkommando I b 7957, Windhuk 29/3/05 Author's translation

13 ELCIN, VII 315 Swakopmund, H Vedder in Swakopmund 31/12/06 to K Ritter, regarding the escape of Herero prisoners from the Woermann camp

14 NNAW, ZBU 4547 Telegram Fuchs in Swakopmund 13/2/05 to Von Trotha Author's translation.

15 Numerous letters written by various civilan companies for POW labour are to be found in NNAW, ZBU 454, Band I-III

16 NNAW, ZBU 454, Band I-III For children one look at the various photographs in the Namibian National archives will suffice to show the employment of minors by the German troops See particularly the photographs in Acc 109 which carry the following appellation Eangebornen Kander helfen Kraal bauen

7 Ibid \& ELCIN II 9 1,7 Privatbrief von Missionar J Bohm aus der Aufstandszeit $1904 \mathrm{ff}$ aus Walfischbay

18 NNAW, ZBU 454, Leutwein in Windhoek 12/2/05 to Bauamt

19 With the outbreak of the war all Herero living in Swakopmund, and those captured along the rallway line towards Karibib, where placed onto the ship SS Eduard Bohlen, which at that stage was anchored off the coast at Swakopmund Not really knowing what to do with the prisoners the authorities decided to offer the male prisoners to South African labour contractor A Hewitt as labour for the mines Hewitt gladly accepted these prisoners, but argued that, as the prisoners were already embarked and at sea, he need prisoners, but argued that, as the prisoners were already embarked and at sea, he need not have to pay customs duty nor 20 mark per labourer as demanded by the German
authontues Hewitt did not have to pay and on 20 January 1904 the SS Eduard Bohlen, with 282 prisoners on board, set sall for Cape Town and the mines of the Rand NNAW, with 282 prisoners on board, set sall for Cape Town and the mines of the Rand NNAW, BSW 7, folıo 110, Letter from the Kasserlich

20 ELCIN, V 31 Chroniken Swakopmund. The author of the text, Dr. Heinnch Vedder, would later become an acclaimed national socialist, anthropologist and historian of Namibian affarrs Following WWII Vedder was appointed to the South Afncan senate as representative of the black population of Namibia His election led in part to the majority of Herero leaving the Rhenish Mission church and establishing their own independent church

21 NNAW, ZBU 454, Dr Fuchs in Swakopmund 29/5/05 to Kasserliche Gouvernement Author's translation. 
22 ELCIN, VII 31 Swakopmund 1, Eich in Okahandja 14/6/05 to Vedder, actung on German military reports mentions the death of 59 men, 59 women and 73 children in the Luderitz camp Conditions in Luderitz were so bad that during the course of 1906 Major von Estroff who was in charge of the military authoritues in Luderitz disobeyed the order of his commanding officers and had the camp moved to a healthier setting

23 NNAW, ZBU 454, Etappenkommando in Windhuk 30/3/05 to Kaiserliche Gouvernement. Author's translation.

24 See for instance NNAW, ZBU 454 D IV I 3 Band 2 Kregsgefangene, Bestandsnachwensung uber Eingeborene Knegsgefangene, Windhoek 18/8/1906

25 NNAW, Bezurksamt Swakopmund 107 (SD63-182) Totenregister für Eingeborene Another aspect that needs to be mentioned here is the conducung of medical experiments
on POWs. Carla Kneger Hinck, in her thesis Uber die Medzzinzshe Versorgung der ehemalgen on POWs. Carla Kneger Hinck, in her thesis Uber dee Medzzinzsche Versorgung der ehemaligen
Kolonie Deutsch Sudwest Afraka (München 1973), basing herself on the Sanitatshercht uber die kasserluche Schutztruppe fur SWA wahrend des Herero und Hottentottenaufstandes fur due Zent vom 1/1/04-31/3/07, Band I (Berlin 1909) 105-106, refers to these acuvitues and to the post-mortems conducted on POWs who had died in the camps. Being more interested in the medical aspects of death Krieger Hinck mentions that in 1906 the 778 post mortems conducted provide a good record of the causes of their death. In later years these actuvitues were followed up by the collection of skulls, which Herero women prisoners of war were forced to scrape can ( Eingeborenangelegenheiten Herero Alte Akte Kolonialamts, Berlin 31/7/08, an den Herrn Gouverneur in Windhuk Specifically deals with Prof Klaatsch's (University of Breslau) request for Herero skulls And Merne KnegsErlebmusse in Deutsch-Sudwest-Afrika, von einem Offizier der Schutztruppe (Minden 1.W. 1907) 114, which carries a photograph with the following text 'A chest of Herero skulls was recently sent by troops from German South West Africa to the pathological institute in Berlın, where they will be subjected to scientufic measurements The Skulls, from which Herero women have removed the flesh with the aid of glass shards 'With thanks to Ms. G Kruger for this reference

26 NNAW, BLU 220, SPS 49 Strafprozesssache gegen die Hererofrau Anna NNAW, BLU 221, SPS 85 Strafprozessache gegen die Herero Kriegsgefangene Justıne, SPS 81 Strafprod BLU 28 (Old notation ZD 96-523) Eingeborenenangelegenheiten E I K Eingeborenen
Unruhen Unruhen

7 NNAW, BSW 107 (Old notation SD 68-204), Entlaufen von Eingeborenen nach Walfischbay, UA $10 / 2$

28 ELCIN, V Chronken 31 Swakopmund RMG, H Vedder All sections of the now destroyed Herero society were to be found amongst those who fled German South West Africa via Walvisbay. One of the many to flee the country was the former Omuhona of Omaruru, Michael Tjisiseta, who led more than 130 fellow prisoners in a break out from the Swakopmund camp

29 NNAW, BWI 406, Akten E.V 8 Kriegsgefangene Eingeborene generalıa begonnen 1/4/ 05-31/3/09 Windhoek 3 April 1908 Durch Verfügung des Kaserlıchen Gouvernements 05-31/3/09 Windhoek 3 Apnl 1908 Durch Verfugung des Kasers hoben.

For an overnew of labour legislation see Tony Emmett, 'Popular Resistance in Namibia, 1920-1925', in Tom Lodge ed, Reszstance and Ideology in Settler Soczetres. Southern African Studies IV (Johannesburg 1986) 10 NNAW, Acc 508 The carrying of metal disks had inivally been recommended by Von Trotha three years earlier.

31 NNAW, ADM 43, Major O'Reilly in Omaruru 20/11/16 to Seci etary for the Protectorate In the case of Omaruru the registers were retained through into the penod after South Africa's occupation of Namibia in 1915

32 B Lau, 'Uncertain certainties The Herero-German war of 1904', Mibagus (Windhoek 1990) 5.

\section{Archives}

\section{The Centre des Archives d'Outre-Mer in Aix-en-Provence}

\author{
ARJEN TASELAAR \\ (Leiden University)
}

Students of French overseas history could hardly imagine a better place to do their research than Aix-en-Provence, the delightful home of the Centre des Archives d'Outre-Mer. Readers of Itnerano will not expect an éloge on this town in the heartland of Provence, about which all travel guide clichés turn out to be true, but readers with experience of the Aix archives will admit that their surroundings easily divert the attention of even the most dedicated historian. The Centre des Archives d'Outre-Mer or CAOM was created in 1966 as an autonomous part of the Archives Nationales. From the outset it was intended to house the archives of the administration of France's former colonies that had gained independence. In 1987, however, the archives of the metropolitan administration were moved from Paris to Aixen-Provence as well. Nowadays, the CAOM houses collections on the former French colonies in Africa, Asia and the Americas. ${ }^{1}$

The CAOM buildings are located in the southern part of Aix-en-Provence on the Chemin du Moulin Detesta, between the Faculty of Arts of the University of Aix-Marseille and one of the university restaurants. The CAOM is open daily, except during weekends, from 09.00 A.M. to 05.00 P.M. and can be visited by anyone who is doing serious research. The lecture room has tables for about fifty readers It is advisable to arrive early, because in the afternoon the room is often quite full. Lunch can be had at the nearby university restaurant, which is not too bad, but will not live up to the expectations of those who regard the whole of France as a culinary paradise (though in this respect Aix-en-Provence itself has much to offer). For those bringing their own lunch, the lawn in front of the CAOM offers an unexpected opportunity for sunbathing.

Of course, no researcher will be able to see all the collections stored in the CAOM. As my own research is focused on twentieth-century Southeast Asia, I will limit my description to the collections that relate to French Indochina. ${ }^{2}$ The first important collection is that of the former Ministry of the Colonies, which covers the nineteenth and twentieth centuries up to 1958. During the greater part of the nineteenth century, the French colonies were under the authority of the Navy Department (département de la Marne). 